\title{
Animated Video in Teaching Reading Comprehension Viewed from the Students' Reading Interest
}

\author{
Ani Sartika Sari \\ Universitas Widya Dharma Klaten \\ anisartika18@gmail.com
}

Article History

Received: 03 Oktober 2021

Reviewed: 06 November 2021

Accepted: 20 November 2021

Published: 30 November 2021

Keywords: animated video, reading comprehension, reading interest

\begin{abstract}
The purposes of this study are to find out whether (1) animated video is effective in teaching reading comprehension, (2) students with high reading interest have better reading comprehension achievement than those with low reading interest, and (3) there is an interaction between the teaching media and the students' reading interest in teaching reading comprehension. This study is experimental research. The population of this study is the students of MTs Negeri Prambanan. Two classes were taken as the sample, and the sampling technique used was cluster random sampling. This study applied tests and a questionnaire in collecting the data and Kolmogorov-Smirnov formula, One Way ANOVA, and multifactor analysis of variance in analyzing the data. Based on the result of data analysis, the research findings are: (1) animated video is effective in teaching reading comprehension of the students in MTs Negeri Prambanan $\left(\mathrm{F}_{\text {obtain }}=7.60\right.$, Sig. Value < 0,05); (2) the students in MTs Negeri Prambanan with high reading interest have better reading comprehension achievement than those with low reading interest $\left(\mathrm{F}_{\text {obtain }}=9.19\right.$, Sig. Value < 0,05); (3) there is an interaction between the teaching media and the students' reading interest in teaching reading comprehension of the students in MTs Negeri Prambanan $\left(\mathrm{F}_{\text {obtain }}=6.15\right.$, Sig. Value $\left.<0,05\right)$. Based on these research findings, it can be concluded that animated video is effective in teaching reading comprehension of the students of MTs Negeri Prambanan. It brings improvement to the students' reading comprehension achievement.
\end{abstract}

\section{INTRODUCTION}

Language is used as a communication tool among people to share their thoughts, ideas, and feelings. English is one of the international languages that is very important for people. People from different countries use English to communicate with one another. In Indonesia, English is a second language taught in elementary school up to college. There are four major skills in English that must be learned: listening, speaking, reading, and writing. One of the skills is reading. Reading becomes an important bridge to the students who want to integrate 
interactive ability (Springer, Harris, \& Dole, 2017). Reading is considered an important skill that needs to be learned and mastered by the students to acquire knowledge and gather information. In teaching reading, the teacher is not only giving a text to the students but also building their consciousness of reading skills. It means that teaching reading has many difficulties from the teachers, the students, the situation of teaching-learning, or the mistakes in choosing method or strategy or media in teaching reading. Khand (2004) states that the problems of teaching reading in schools are caused by the existing textbooks being old, teacher-centered, and less effective in learners' situations. In addition, the teaching method of the school is not learner-centered where the role of learners is not that of active participants, the teachers' activities mainly consist of simple oral presentation throughout class time, no proper tasks or exercises for intensive reading are given in class, and rare use of audiovisual media are among problems occurred in teaching reading in schools.

The problems of teaching reading are also faced by the English teacher in MTs Negeri Prambanan. Most of the students are bored when they have to read a text, especially a long text, so they have difficulties comprehending the text. Besides, the teacher only uses a textbook as media for teaching reading. The teachers should use other media to overcome the teaching problem. The teacher can use technology in media that allows learners to be active, promotes interest in learning, and positively impacts learner achievement (Mark, 2018). Then, one of the media suitable with the facility in the class is animated video. An Animated video with an English title can be a helpful teaching tool for English teachers to use in class, and they could improve learners' English ability and increase learning motivation ( $\mathrm{Su} \&$ Eleen, 2015). Hence, the students will become more active in reading. In this study, the researcher tried to use animated video that provides moving pictures, sounds and subtitles to make students interested in reading material. Animated video also brings illustrations about the material and can help the students to have a good pronunciation. It means that animated video has a good effect on teaching reading. Another factor that influences teaching reading is reading interest. Interest has a powerful impact on both the cognitive and affective aspects of reading. It affects both how we think and how we feel about what we read (Renninger \& Bachrach, 2015). It means that reading interest brings an impact on how the students comprehend what they read. The students having high reading interest can understand the text better than students having low reading interest. 
Based on the explanation, animated video is a medium of teaching reading for the students in MTs Negeri Prambanan since it can promote their reading interest. To achieve the conclusion, this study questions whether whether (1) animated video is effective in teaching reading comprehension, (2) students with high reading interest have better reading comprehension achievement than those with low reading interest, and (3) there is an interaction between the teaching media and the students' reading interest in teaching reading comprehension

\section{LITERATURE REVIEW}

Arsyad (2017) states that media is the messages mediator from the sender to the receiver. It also delivers a message from the sender to the receiver to stimulate the mind, feelings, concerns, interests, and the willingness of learners so that learning occurs to achieve the learning objectives effectively (Sukiman, 2012). The students can build their interest, feeling, mind, and spirit to follow the teaching-learning process with media. One of the media is video. It is capable of simultaneously displaying images and sounds (Sukiman, 2012). Smaldino (2002) defines it as the electronic storage of moving images that employs motion pictures to present a message.

Hannafin \& Rieber in Jolly (2003) defines animation as a series of computer screens illustrating movement. Furthermore, Schnotz \& Lowe in Rosen (2009) states that animation is a dynamic representation that can be used to make a change and complex processes explicit to the learner. Hence, the animation is a computerized simulation of processes using images to form a motion picture. It can be concluded that animated video is electronic media that uses motion-picture or simulated objects that can be used to present a message in language learning. It also contains moving pictures, sounds, and subtitles on the screen. And, the subtitle, especially English one, is a helpful teaching tool for English teachers to use in class.

Reading is an important bridge for students to have an integrating interactive ability. The students apply their abilities in understanding the content of the text when they read a text. Hence, reading becomes a process of interaction between the reader and the text to get information and respond to a message from the text. Reading comprehension is a process of reading in order to build understanding (Tarchi, 2017). Another expert, Pardo in Al Ghazo (2015), defines comprehension as a process in which the readers construct meaning by interacting with a text through the combination of prior knowledge and previous experience, information in the text, and the stance the reader takes in relationship to the text. Reading 
comprehension is a process of visualizing, understanding, and interpreting information to get the text's message.

Interest plays an important role in teaching reading comprehension. Interest is a situation arising from the desire to perform reading activities and achieve a goal (Mahaputri, 2016). Then, reading interest is not only driven by the individual preferences for the text itself but also can be elicited by external manipulations that alter the context in which reading occurs (Schraw and Dennison in Hidi, 2001). Moreover, the US Department of Education in Khairuddin (2013) defines reading interests as to whether or not students like to read in their spare time or at home or whether they like to go to the library. Besides, reading interest is also defined by the number of books read in a month, the number of times students read in a week, and the favorite genres and types of English reading materials. It can be concluded that reading interest is attention or someone's heart inclination to do a reading activity.

\section{METHODOLOGY}

\section{Research Design}

This study applies experimental design with the form of factorial experimental design. A factorial plan $2 \times 2$ is used to know the effects of independent variables on dependent variables. The animated video is the independent variable of this study, and the dependent variable is the students' reading comprehension. At the same time, the moderate variable is the students' reading interest.

\section{Participants}

The population of the study is the eighth grade class of MTs Negeri Prambanan that consists of 8 classes. The total population is 237 students. The sample of the study is two classes of the eighth grade class of MTs Negeri Prambanan in the academic year of 2016/2017. Then the researcher used cluster random sampling in the sampling technique.

\section{Instruments}

The study's instruments are tests and a questionnaire. The kinds of tests are pretest and posttest tested in control and experimental groups. There are 100 questions about the descriptive texts that are tried out. The result of the try-out test is then analyzed to know the instrument's validity and reliability and to know whether any of the items should be revised 
or not. The questionnaire uses five alternatives based on the Likert Scale type. The Likert scale is a scale used to measure someone's opinion or perception of the object. It is a scale with a number of points, usually at least three but not more than seven (Siregar, 2017). The researcher modified Ade's questionnaire to construct the questionnaire. Ade's questionnaire was used for the seventh-grade students of MTs Negeri Gondangrejo in the academic year of 2013/2014. Meanwhile, this study researched the eighth-grade students of MTs Negeri Prambanan. Hence, the researcher had to modify the questionnaire because the language complexity between the eighth and seventh-grade students differs.

\section{Data Analysis}

In analyzing the data, this study applies a normality test that is the KolmogorovSmirnov formula, then the homogeneity test that is One Way ANOVA and multifactor analysis of variance for the hypothesis test.

\section{FINDINGS AND DISCUSSION}

\section{Animated Video is Effective in Teaching Reading Comprehension}

The hypothesis of this study is there is a significant difference in teaching reading comprehension by using animated video. The hypothesis test is done by using the Multifactor Analysis of Variance test through SPSS 22.0 for windows.

The data description includes pretest and posttest scores from the students' reading comprehension tests in the control and experimental groups. Pretest was conducted in the control group and experimental groups before posttest. The control group consists of 30 students: 16 boys and 14 girls. The results are that the highest score is 84 , the lowest score is 16 , the mean is 44.13 , the mode is 44.00 , the median is 44.00 , and the standard deviation is 18.57. The experimental group consists of 31 students: 15 boys and 16 girls. The results are that the highest score is 80 , the lowest score is 12 , the mean is 52.39 , the mode is 52.00 , the median is 52.00 , and the standard deviation is 15.23 .

Furthermore, the following are the results of the posttest in both the control group and the experimental group, which are: the highest score in the control group is 88, the lowest score is 40 , the mean is 61.86 , the mode is 64 , the median is 62.00 , and the standard deviation is 12.33 ; the highest score in the experimental group is 84 , the lowest score is 44 , the mean is 68.38 , the mode is 64 , the median is 68,00 , and the standard deviation is 8.72 . 
The results show that the mean score of the students in the experimental group (68.38) is higher than the students in the control group (61.86). It means that teaching reading comprehension using animated video is effective in teaching reading comprehension.

Table 1. The summary of multifactor analysis of variance

\begin{tabular}{ccccccc}
\hline Source of Variance & $\begin{array}{c}\text { Sum of } \\
\text { Square }\end{array}$ & df & $\begin{array}{c}\text { Mean of } \\
\text { Square }\end{array}$ & Fo & Ft (.05) & $\begin{array}{c}\text { Sig. } \\
\text { Value }\end{array}$ \\
\hline $\begin{array}{c}\text { Between Columns } \\
\text { (Teaching Media) }\end{array}$ & 622.70 & 1 & 622.70 & 7.60 & 4.12 & 0.009 \\
\hline
\end{tabular}

The summary of multifactor analysis of variance shows that Sig. Value (0.009) is lower than $a(0,05)$, and $F_{\text {obtain }}(7.60)$ is higher than $F_{\text {table }}(4.12)$. It means that the null hypothesis $\left(\mathrm{H}_{0}\right)$, which states that there is no significant difference in reading comprehension by using animated video, is rejected. Hence, teaching reading comprehension using animated video to the students of MTs Negeri Prambanan is effective.

Video is an excellent way to spark students' interest in a class text, it is served as the catch for the reading activity, and the hold was reading a captivating, well-written text (Poedjiastutie et al., 2018). Furthermore, Harmer (2015) states that video makes the students not only listen to the language but also see it in supporting comprehension. The video contains gestures and expressions that allow the students to interpret the video in a deeper way. Besides, it will enable the learners to access more information because the students can listen and see what is happening simultaneously. Then, one of the media that is suitable with the facility in the class is an animated video. Animated video provides moving pictures and sounds, which is a good combination to make the students comprehend the text well. Furthermore, it also helps improve reading ability and have good pronunciation when they read the text. By using animated video, the students can get the benefit of audio and visual supports. It means that animated video has a good effect on teaching reading comprehension.

\section{Students with High Reading Interest Have Better Reading Comprehension Achievement than Those with Low Reading Interest}

The students' reading interest is measured by a questionnaire using the Likert Scale type. The students' reading interest in the research is classified into high reading interest and low reading interest. The following is the results of the reading comprehension posttest score in the control group based on the students' reading interest. The highest score of the students having a low interest in reading is 68 , and the lowest score is 44 . The mean is 56 , the mode is 
60 , the median is 60 , and the standard deviation is 9.38 . The highest score of the students having a high interest in reading is 88 , and the lowest score is 56 . The mean is 72 , the mode is 56 , the median is 72 , and the standard deviation is 11.62 .

Moreover, the following is the results of the reading comprehension posttest score in the experimental group based on students' reading interest. The highest score of the students having a low interest in reading is 84 , and the lowest score is 60 . The mean is 71.2 , the mode is 72 , the median is 72 , and the standard deviation is 7.50 . The highest score of the students having a high interest in reading is 84 , and the lowest score is 64 . The mean is 72.8 , the mode is 64 , the median is 74 , and the standard deviation is 7.00 .

The data show that the mean score of students with a high reading interest is higher than those with low reading interest. It means that the students' reading comprehension with high reading interest is better than those with low reading interest.

Table 2. The summary of multifactor analysis of variance

\begin{tabular}{ccccccc}
\hline Source of Variance & $\begin{array}{c}\text { Sum of } \\
\text { Square }\end{array}$ & df & $\begin{array}{c}\text { Mean of } \\
\text { Square }\end{array}$ & Fo & Ft (.05) & $\begin{array}{c}\text { Sig. } \\
\text { Value }\end{array}$ \\
\hline $\begin{array}{c}\text { Between Rows } \\
\text { (Reading Interest) }\end{array}$ & 753.47 & 1 & 753.47 & 9.19 & 3.27 & 0.005 \\
\hline
\end{tabular}

Based on the data above, Sig. Value $(0.005)$ is lower than a $(0,05)$, and $F_{\text {obtain }}(9.19)$ is higher than $\mathrm{F}_{\text {table }}$ (3.27). It can be concluded that students with high reading interest demonstrate a significantly different result in their learning from the ones having low reading interest.

The teacher can use technology in media that allows learners to be active, promotes interest in learning, and can have a positive impact on learner achievement (Mark, 2018). The students in the experimental group were taught by using an animated video that made them interested and focused on the material in the video. They could comprehend the text well and understand the message of the material. Besides, they could improve their pronunciations. Meanwhile, the control group was taught by existing media that was textbook. The researcher found that the students were so bored in joining the lesson. They did not give positive responses to the material. Then, reading interest is important in enhancing students' success in school and out of it Khairuddin (2013). The students with high reading interest are more capable of reading a text. Besides, they can comprehend the text better than the students having low reading interest. It makes the students with high reading interest have better achievement than the students with low reading interest. 


\section{There is an Interaction Between the Teaching Media and the Students' Reading Interests in Teaching Reading Comprehension}

Table 3. The summary of multifactor analysis of variance

\begin{tabular}{ccccccc}
\hline Source of Variance & $\begin{array}{c}\text { Sum of } \\
\text { Square }\end{array}$ & df & $\begin{array}{c}\text { Mean of } \\
\text { Square }\end{array}$ & Fo & Ft (.05) & $\begin{array}{c}\text { Sig. } \\
\text { Value }\end{array}$ \\
\hline $\begin{array}{c}\text { Columns by Rows } \\
\text { (Interaction) }\end{array}$ & 504.38 & 1 & 504.38 & 6.15 & 3.27 & 0.018 \\
\hline
\end{tabular}

The table above shows that Sig. Value (0.018) is lower than a $(0,05)$, and $F_{\text {obtain }}(6.15)$ is higher than $F_{\text {table }}$ (3.27). It can be concluded that there is an interaction effect between the two variables, the teaching media and students' reading interest. It means that the null hypothesis $\left(\mathrm{H}_{0}\right)$, which states that there is no interaction between teaching media and students' reading interest, is rejected.

Teaching media and reading interests are important in the teaching and learning process. Then, interest has a powerful impact on both the cognitive and affective aspects of reading. It affects both how we think and how we feel about what we read (Renninger \& Bachrach, 2015). It can be a good combination if the students with high reading interests are taught using animated video as teaching media. It means that animated video is more appropriate for students with high reading interest because they have more attention and mastered vocabulary than those with low reading interest. They also have prior knowledge that is very helpful for making a prediction. Hence, they focus on how to develop their abilities in comprehending the text. Animated video is an innovation in understanding the text. The students do not just read, but they also see and hear the text. It makes them easier to comprehend the text.

While the animated video is less appropriate for the students who have a low reading interest, they usually read the text they have to read, not what they want to read. Besides, they have a lack of vocabulary mastery. Hence, they need media that can develop the mastered vocabulary before they have to comprehend the text. It is not easy to read the text quickly, so they need media that allows them to read slowly, such as textbooks. The textbook is more appropriate for students with low reading interest. By using a textbook, the students can be slowly accompanied by extensive note-taking and skimming rapidly. It can help them to engage and hold their interest first and develop their mastered vocabulary.

It can be concluded that there is an interaction between learning media employed by the teachers and the students' reading interest. The students with higher reading interest have 
better suitability to be taught using animated video, and students with lower reading interest will be taught using a textbook.

\section{CONCLUSION}

Animated video is effective in teaching reading comprehension of the students in MTs Negeri Prambanan. It can be seen from Sig. Value (0.009) that is lower than a $(0,05)$ and $F_{\text {obtain }}(7.60)$ that is higher than $F_{\text {table }}$ (4.12). It means that the null hypothesis $\left(\mathrm{H}_{0}\right)$, which states that there is no significant difference in reading comprehension by using animated video, is rejected. Hence, teaching reading comprehension using animated video to the students of MTs Negeri Prambanan is effective.

Moreover, the students of MTs Negeri Prambanan with high reading interest have better achievement in reading comprehension than those with low reading interest. It can be seen from Sig. Value $(0.005)$ that is lower than a $(0,05)$ and $F_{\text {obtain }}(9.19)$ that is higher than $F_{\text {table }}$ (3.27). It means that the students with high reading interest demonstrate a significantly different result in their learning from the ones having low reading interest.

While Sig. Value $(0.018)$ that is lower than a $(0,05)$ and $F_{\text {obtain }}(6.15)$ that is higher than $F_{\text {table }}$ (3.27) show that there is an interaction effect between the two variables, the teaching media, and the students' reading interest. It can be concluded that animated video is effective in teaching reading comprehension of the students of MTs Negeri Prambanan. It brings improvement to the students' reading comprehension achievement.

\section{LIMITATION AND STUDY FORWARD}

The media of this study is animated video. The focus of this study is how to comprehend a descriptive text correctly. The students' reading achievement is measured by reading comprehension tests. This study is expected to be input in the English teachinglearning process. The teachers can use this study as a source of their instruction in the teaching and learning process. They can improve their teaching learning activities by choosing appropriate media to enhance their students' reading comprehension of descriptive text to create an interesting and motivating atmosphere. It also gives a profitable description for any further researcher who wants to study the same case. This study becomes helpful information and a useful reference to the next study. 


\section{ACKNOWLEDGEMENT}

The researcher would like to thank all of those who had helped, supported, and suggested during the process of writing this article. This goes to:

1. Prof. Dr. Triyono, M.Pd., Widya Dharma University Klaten

2. Prof. Dr. Herman J Waluyo, M.Pd., Widya Dharma University Klaten

3. Dr. Hersulastuti, M.Hum., Widya Dharma University Klaten

4. Sriyanto, M.Ag., MTs Negeri Prambanan

5. Yuto Sujarwo, S.Pd., MTs Negeri Prambanan

\section{REFERENCES}

Al-Ghazo, Abeer. (2015). The effect of sq3r and semantic mapping strategies on reading comprehension learning among Jordanian university students. International Journal of English and Education, 4(3), 92-106.

Arsyad, Azhar. (2017). Media pembelajaran. Rajawali Pers.

Harmer, Jeremy. (2015). The practice of English language teaching. London Pearson.

Hidi, Suzanne. (2001). Interest, reading, and learning: theoretical and practical considerations. Educational Psychology Review,13(3), 191-209.

Jolly, Sushma. (2003). Studying the effectiveness of animations and graphics with text on fourth, fifth and sixth graders. Nebraska University.

Khairuddin, Zurina. (2013). A study of students' reading interests in a second language. International Education Studies, 6(11), 160-170.

Khand, Ziauddin. (2004). Teaching reading skills: problems and suggestions. Journal of Research (Faculty of Languages \& Islamic Studies), 5, 43-56.

Mahaputri, Dwi Settya. (2016). The effect of awareness raising technique towards students' achievement and reading interest. Al-Ta'lim Journal; Padang, 23(3), 232-240.

Mark, Stevens. (2018). Technology enhanced learning for English language learners [Doctoral dissertation, George Mason University]. ProQuest Dissertations Publishing. https://www.proquest.com/docview/2203805608/3D5E647373A34514PQ/1

Poedjiastutie et al. (2018). Task-based language teaching: an alternative approach in teaching reading comprehension in Indonesia. Journal of Asia TEFL; Seoul, 15(3), 856-863.

Renninger, K. A., \& Bachrach, J. E. (2015). Studying triggers for interest and engagement using observational methods. Educational Psychologist, 50(1), 1-12. 
Rosen, Yigal. (2009). The effects of an animation-based online learning environment on transfer of knowledge and on motivation for science and technology learning. Journal of Educational Computing Research, 40(4), 1-28.

Siregar, Syofian. (2017). Metode penelitian kuantitatif: dilengkapi dengan perbandingan perhitungan manual dan SPSS. Kencana Prenada Media Group.

Smaldino, Sharon, E. (2002). Instructional technology and media for learning. Pearson.

Springer, Sheree E., Harris, Samantha, \& Dole, Janice A. (2017). From surviving to thriving: four research-based principles to build students' reading interest. International Literacy Association, 71(1), 43-50.

Su, Shu-Chin \& Eleen, Liang. (2015). Using subtitled animated cartoons and textbook-based CDs to test elementary students' English listening and reading comprehension in a cram school. International Journal of Applied Linguistics \& English Literature; Footscray, 4(1), 106-114.

Sukiman. (2012). Pengembangan media pembelajaran. Pedagogia.

Tarchi, Christian. (2017). Comprehending and recalling from text: the role of motivational and cognitive factors. Issues in Educational Research, 27(3), 600-619. 